\title{
IMPACT OF TRICHODERMA SP. ON THE DEVELOPMENT OF HETEROBASIDION ANNOSUM IN DECAYED UNDERSTORY PICEA ABIES STUMPS
}

\author{
Kristīne Kenigsvalde ${ }^{1}$, Dina Nitiša ${ }^{1}$, Dace Saulite ${ }^{1}$, Kari Korhonen ${ }^{2}$, Lìvija Vulfa ${ }^{3}$, \\ Vizma Nikolajeva $^{3}$, Dārta Kḷaviṇa ${ }^{4}$, Lauma Brūna ${ }^{4}$, and Tālis Gaitnieks ${ }^{1, \#}$ \\ ${ }^{1}$ Latvian State Forest Research Institute "Silava", Rīgas iela 111, Salaspils, LV-2169, LATVIA \\ ${ }^{2}$ Finnish Forest Research Institute Metla, Jokiniemenkuja 1, Box 18, FI-01301, Vantaa, FINLAND \\ ${ }^{3}$ Faculty of Biology, University of Latvia, Kronvalda bulv. 4, Rīga, LV-1586, LATVIA \\ ${ }^{4}$ Forest Sector Competence Centre, SIA "MNKC", Dzērbenes iela 27, Rīga, LV-1006, LATVIA \\ \# Corresponding author, talis.gaitnieks@silava.Iv
}

Contributed by Tālis Gaitnieks

\begin{abstract}
Heterobasidion annosum (Fr.) Bref. s.l. causes significant economic losses in conifer forests. Therefore, to reduce the spread of the infection surfaces of freshly cut conifer, stumps are commonly treated with biological control agents. Trichoderma sp. shows very strong antagonistic effect against $\mathrm{H}$. annosum in vitro, but relatively few field studies have been conducted. Moreover, most of previous studies examined the impact of Trichoderma sp. on $\mathrm{H}$. annosum in healthy conifer stumps. The aim of our work was to evaluate the effect of Trichoderma sp. against $\mathrm{H}$. annosum in already decayed understory spruce stumps. In total, 75 decayed spruce stumps were surveyed. Part of the spruce stumps were left as a control, and the others were treated with one of two Trichoderma isolates (T472 and T945) belonging to two different species: T. viridescens and $\mathrm{T}$. viride. The occurrence of $\mathrm{H}$. annosum was evaluated 3 and 12 months after treatment. The main results were that the area of previously healthy wood occupied by $\mathrm{H}$. annosum was larger in control stumps in comparison with treated stumps, but the differences were not statistically significant.
\end{abstract}

Key words: Picea abies, decayed stumps, Trichoderma, Heterobasidion.

\section{INTRODUCTION}

Heterobasidion annosum (Fr.) Bref. s.l. causes significant economic losses in conifer forests. In Latvia, the losses are estimated to be 800-4790 EUR ha ${ }^{-1}$, depending on stand age and productivity (Gaitnieks et al., 2007). In stands already infected, $H$. annosum spreads from infected to healthy trees via root contacts. Spread of $H$. annosum is very rapid in forest sites previously used for agriculture (Korhonen and Stenlid, 1998). It is considered that one of the reasons why conifer plantations established on agricultural lands have a high risk of $H$. annosum infection is the lack of antagonistic microflora in soil, especially Trichoderma sp. (Johansson and Marklund, 1980; Sierota and Kwaśna, 1998; Gaitnieks et al., 2009).

To reduce the formation of new infection centres in healthy stands during logging, the surfaces of freshly cut conifer stumps are treated with chemical or biological control agents (Thor, 2005). The most frequently used biological control agent contains spores of fungus Phlebiopsis gigan- tea (Fr.) Jülich (Pratt et al., 2000). The Finnish preparation Rotstop ${ }^{\circledR}$ has been used for stump treatment in Latvia since 2007 (Kenigsvalde et al., 2011). Stump treatment with $P$. gigantea reduces the infection of stumps by spores of $H$. annosum, but if a stump is already infected by $H$. annosum, $P$. gigantea is not able to replace it, and $H$. annosum can live in the stump for more than 40 years (Piri, 1996). Instead, $P$. gigantea disappears from pine stumps after about three years and from spruce stumps after six years (Vainio et al., 2001).

Several fungal species (as Fomitopsis pinicola, Resinicium bicolor, Sistotrema brinkmannii, Trichodema sp., and others) have been studied as possible antagonists against $H$. annosum. However, the obtained results were variable, and only a few species have been tested under field conditions (Holdenrieder and Greig, 1998).

Biological preparations containing Trichoderma sp. spores are widely used for control of different plant pathogens in agriculture (Lielpetere, 2009) and their inhibiting effect on 
the growth of Ganoderma adspersum, Inonotus hispidus, and Polyporus squamosus in pruning wounds of broadleaved trees was demonstrated (Schubert et al., 2008). Trichoderma sp. shows very strong antagonistic effect against $H$. annosum in vitro (Hanso and Hanso, 1985). At present, however, only few data are available on the effect of Trichoderma sp. on development of $H$. annosum in conifer stumps, and the obtained results are contradictory. For example, Kallio and Hallaksela (1979) showed that T. viride had a negative impact on the development of $H$. annosum in spruce stumps, but Nicolotti et al. (1999) concluded that $T$. harzianum did not protect stumps against $H$. annosum infection. La Porta et al. (2001) analysed the effect of Trichoderma treatment on Norway spruce in Italy; better results were obtained on billets but no control effect was observed on stumps.

Most of the previous experiments were performed using Trichoderma for the protection of healthy spruce stumps against $H$. annosum infection. To our knowledge there are no investigations on the impact of Trichoderma in spruce stumps with $H$. annosum decay. Stumps of spruce trees with $H$. annosum butt rot contain also sound wood, and biological stump treatment may restrict the colonisation of this wood by the pathogen. Rishbeth (1951) observed that Trichoderma sp. can replace $H$. annosum in decayed pine roots under controlled conditions. Also Capretti and Mugnai (1989) observed that Trichoderma sp. can colonise decayed roots. Kuhlman and Hendrix (1964) noted that T. viride could grow in Pinus echinata wood that is fully colonised by $H$. annosum and even replace it in decayed stumps. Meredith (1960) concluded that Trichoderma sp. is not able to compete with $P$. gigantea or $H$. annosum on freshly cut wood, but its frequency of occurrence and activity increase at later stages of decay. Also Vasiliauskas et al. (2005) and Varese et al. (2003) observed the increase of Trichoderma sp. with time in Norway spruce stumps.

Therefore, it seems meaningful to investigate the impact of other fungi on $H$. annosum in already infected substrate. The aim of this work was to study the impact of Trichoderma sp. on the development of $H$. annosum mycelium in decayed stumps of understory spruce.

\section{MATERIALS AND METHODS}

The experiment was conducted in the Kalsnava Forest Research Station management area in eastern Latvia, in compartment 13, subcompartment 13 . The size of the experimental plot was approximately $60 \times 100 \mathrm{~m}$. The stand was composed of 113-year-old Scots pine with 21-46-year- old Norway spruce in the understory.

In 4 August 2011, a total of 258 randomly selected Norway spruce trees were manually cut leaving $0.5 \mathrm{~m}$ high stumps. A wood disc with $3 \mathrm{~cm}$ thickness was cut from all stumps showing signs of root and butt rot (138 stumps) and transported to the laboratory.
The discs were debarked, washed with a stiff brush under running tap water, and incubated for 5-7 days in loosely closed plastic bags at room temperature. The lower side of each disc was investigated. Decay caused by $H$. annosum was found in 76 stumps. A grid consisting of $0.49 \mathrm{~cm}^{2}$ squares was fixed on to the disc with pins, and the area colonised by $H$. annosum conidiophores was marked on the disc using a dissection microscope (Sun et al., 2009). Then a sheet of transparent paper was placed on the surface of the disc and the area of $H$. annosum was redrawn and measured using a planimeter (PLANIX 10S "Marble", Tamaya).

The stumps containing $H$. annosum decay were divided in three equal groups, each with approximately the same distribution of different diameter classes and different degrees of decay. Twenty-four stumps were treated with Trichoderma T472, 26 stumps with Trichoderma T945, and 25 stumps with tap water only (below these stumps are called "untreated"). The stump treatment was carried out one week after cutting the trees. Before treatment, a disc with $2 \mathrm{~cm}$ thickness was cut from the stump and discarded.

Trichoderma T945 (Trichiderma viride, isolated from soil) and Trichoderma T472 (Trichoderma viridescens, isolated from rhododendron) were selected according to their known high antagonistic effect against Heterobasidion spp. (three strains of $H$. annosum s.s. and four strains of $H$. parviporum) in laboratory tests on malt extract agar media at low temperatures (Nikolajeva el al., 2012). For stump treatment, the Trichoderma strains were cultivated in Petri dishes on malt extract agar (MEA) medium for 4 weeks at ca. $20{ }^{\circ} \mathrm{C}$ in the dark. Spore suspensions were prepared 2-4 hours before the experiment by rinsing the spores from one Petri dish to $250 \mathrm{~mL}$ of tap water. The colony was agitated with a glass triangle during rinsing. The spore suspension was shaken vigorously and $0.5 \mathrm{~mL}$ of it was spread evenly on a Petri dish with 2-3-week-old MEA medium. Using a microscope, spores within 30 sight fields per dish were counted, and the number of spores per dish was calculated taking into account the area of the sight field and the area of the agar plate. Spore concentration in the treatment suspension was adjusted to ca. $10^{7} \mathrm{cfu} \mathrm{mL}^{-1}$. Stumps were treated manually using a hand sprayer.

Three months after start of the experiment, in October 2011, the stumps of each of the three treatment variants $(25,26$, and 24 stumps, respectively) were divided in two approximately equal parts, each consisting of 12 or 13 stumps (Table 1). One part of the stumps was sampled, the other part was left intact to be sampled later. First, a $2 \mathrm{~cm}$ thick disc was cut from the stump surface and discarded. The second disc $(2 \mathrm{~cm}$ thick) and third disc ( $4 \mathrm{~cm}$ thick) were placed in plastic bags and transported to the laboratory. The area occupied by $H$. annosum on the lower side of each disc was measured. Hence the $50 \mathrm{~cm}$ high stumps were investigated at two heights, 46 and $42 \mathrm{~cm}$.

The other part of the stumps was sampled as described above on August 2012, one year after start of the experiment. 
Table 1

CHARACTERISTICS OF THE STUMPS AT THE BEGINNING OF THE EXPERIMENT IN AUGUST 2011

\begin{tabular}{l|c|c|c|c}
\hline Treatment & Number of stumps & $\begin{array}{c}\text { Average stump } \\
\text { diameter, cm }\end{array}$ & $\begin{array}{c}\text { Total area of sample discs, } \\
\mathrm{cm}^{2}\end{array}$ & $\begin{array}{c}\text { Total area of H. annosum, } \\
\mathrm{cm}^{2}\end{array}$ \\
\hline Untreated & 25 & $8.03 \pm 0.46$ & 1209 & 331 \\
T945 & 26 & $7.51 \pm 0.30$ & 1006 & 346 \\
T472 & 24 & $8.14 \pm 0.36$ & 1148 & $34.39 \%$ \\
\end{tabular}

* The percentages are based on summed areas from all sample discs within each treatment variant

The effect of Trichoderma treatment on H. annosum was calculated on the basis of wood occupied by H. annosum on sample discs cut from treated and untreated stumps at the beginning of the experiment, after three months, and after one year. The area colonised by $H$. annosum on a sample disc was related to the total disc area including sapwood and heartwood. Statistical significance of differences between treatments was analysed using a Student's t-test.

\section{RESULTS}

Visible decay was observed on 138 of 256 analysed stumps (53.9\%). Decay caused by $H$. annosum was identified from 76 stumps $(29.7 \%)$. In the further experiment 75 stumps were analysed. Their diameter varied from 4 to $14 \mathrm{~cm}$. Area occupied by $H$. annosum on sample discs taken from these stumps varied from 0.25 to $50.4 \mathrm{~cm}^{2}$. Main characteristics of the stumps with $H$. annosum decay are shown in Table 1. There were no significant differences of any analysed parameters among treated and untreated stump groups at the beginning of the experiment $(p>0.05)$.

Three months after stump treatment, in October 2011, a part of the stumps were investigated at two heights, $46 \mathrm{~cm}$ and $42 \mathrm{~cm}$. Statistical analysis revealed no significant differences between untreated stumps and stumps treated with Trichoderma (Fig. 1). Trichoderma was found only in two analysed stumps.

One year after stump treatment, in August 2012, the other part of the stumps were investigated at heights $46 \mathrm{~cm}$ and $42 \mathrm{~cm}$ (Table 2). There was one statistically significant change compared to October 2011: area occupied by $H$. annosum was significantly larger in stumps treated with Trichoderma T945 (at height $46 \mathrm{~cm}$ ). There were two statistically significant changes compared to the beginning of the experiment in August 2011: the area occupied by $H$. annosum (at height $46 \mathrm{~cm}$ ) was larger in untreated stumps $(p<0.05)$, but it was significantly larger also in stumps treated with Trichoderma T945 at height $46 \mathrm{~cm}(p<$ 0.05 ). When the area of $H$. annosum in stumps at height 42 $\mathrm{cm}$ was compared to the situation at the beginning of the experiment one year earlier, no statistically significant differences were found between any treatment variants. A general trend was that the proportion of $H$. annosum decay increased with time and towards the base of the stump (Fig. 1). Trichoderma was present only in two analysed stumps.

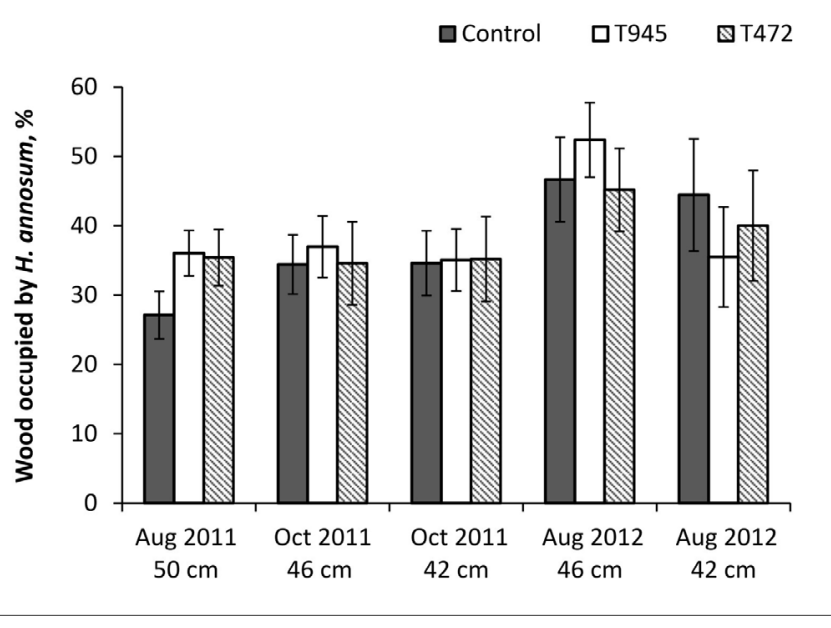

Fig. 1. Percentage of stump wood occupied by $H$. annosum at different sampling times and at different heights in stumps.

The effect of Trichoderma was analysed using two calculation methods - occupied area of $H$. annosum calculated from total area of all analysed discs (areas on sample discs summed) and average occupations of $H$. annosum calculated from individual stumps: for untreated control stumps at the beginning of experiment in August 2011 it was $27.37 \%$ and $27.10 \%$, for stumps treated with Trichoderma T945 it was $34.39 \%$ and $36.00 \%$ and for Trichoderma T472 it was $34.15 \%$ and $35.40 \%$, respectively. There were no statistically significant differences also comparing different treatments at different levels after one year using these calculation methods (data are not shown).

\section{DISCUSSION}

Our study did not reveal any clear effect of stump treatment with Trichoderma on the spread of $H$. annosum in stumps with $H$. annosum butt rot. A general trend was that the proportion of wood occupied by $H$. annosum in the stump increased with time and decreased with sampling height (Fig. 1 ), which can be explained by the conical form of the decay column in spruce stem stems. In Latvian forests, the mean length of stem decay caused by $H$. annosum in mature spruce ( 100 years old) is $6.7 \mathrm{~m}$ (Arhipova et al., 2011). The spruces in our experimental plot were younger, 21-46 years old, and the mean length of the decay column was $2.7 \mathrm{~m}$ (Gruduls et al., 2012). 
The increase of $H$. annosum-infected wood towards the stump base was greater in untreated stumps compared to the stumps treated with Trichoderma (Fig. 1) but the difference was not statistically significant. The slightly greater increase of $H$. annosum-infected wood in untreated stumps may be due to the inhibiting effect of Trichoderma in treated stumps, but it may also be an indication of spore infections by $H$. annosum to the sound wood of stumps. This kind of spore contamination is likely because fruit bodies of $H$. annosum were found in the experimental site. On the other hand, rapid drying of the relatively small-sized stumps in this experiment may restrict the germination of $H$. annosum spores on stump surfaces and subsequent mycelial growth (Benz-Hellgren and Stenlid, 1998). If the decreased expansion of $H$. annosum in lower parts of the stump in treated stumps is due to limiting effect of Trichoderma, this effect is very small.

In the present work, the poor growth of Trichoderma in stump wood, in particular in deeper parts of the stumps, seems to contradict the possible limiting effect of this fungus on spread of $H$. annosum in stump wood. Three months after stump treatment, typical Trichoderma infection was seen on sample discs of two stumps only (at levels $4 \mathrm{~cm}$ and $8 \mathrm{~cm}$ from stump surface). Also, one year after treatment, Trichoderma infection was found only in two other stumps. This was somewhat unexpected, because Trichoderma is a relatively common fungus in spruce stumps, particularly in older ones. Vasiliauskas et al. (2005) observed an increase of the proportion of Trichoderma with time in Norway spruce stumps: four years after stump treatment with Rotstop, Trichoderma sp. were isolated from 16.7-17.1\% control stumps, as well as from treated stumps, but after six years Trichoderma was found in $37.1-40 \%$ of stumps. Also, Varese et al. (2003) reported an increase of the proportion of Trichoderma sp. with time in Norway spruce stumps.

There are limited data about presence Trichoderma on living wood. Living trees normally reject Trichoderma infection. Lygis et al. (2004) isolated Trichoderma sp. from Pinus sylvestris stem base. Schubert et al. (2008) treated pruning wounds of several broadleaved trees with Trichoderma and tried to reisolate the fungus at different time intervals (2-30 months). Maximum isolation frequency was recorded at depth $1 \mathrm{~cm}$, but at depth $5 \mathrm{~cm}$ no isolates were obtained. In the present study, a number of tested stumps had root contacts with living spruce trees and may have remained alive for some time. This may have restricted the growth of Trichoderma. In another experiment, we treated coniferous billets with Trichoderma suspension; six weeks later pronounced growth of Trichoderma mycelium in treated sectors was observed (unpublished data).

Temperature has significant impact on Trichoderma sp. activity. Kallio and Hallaksela (1979) noted that T. viride cannot protect freshly cut stumps of Norway spruce from $H$. annosum in the cold season. Rishbeth (1951) analysing $T$. viride effect on $H$. annosum on Pinus roots in laboratory conditions at temperatures 5,10 , and $15{ }^{\circ} \mathrm{C}$ concluded that the impact of Trichoderma decreases at $5{ }^{\circ} \mathrm{C}$. However, one of our Trichoderma isolations T945 in vitro showed pronounced antagonism against $H$. annosum also at $+4{ }^{\circ} \mathrm{C}$ (Nikolajeva el al., 2012).

In our experiment, Trichoderma, in spite of its antagonistic properties against several plant pathogens, did not prove to be effective against Heterobasidion infection present in spruce stumps. Other control methods, such as change of tree species or removal of stumps may be necessary for controlling the disease in heavily infected sites (Vasaitis et al., 2008). However, it might be useful to continue experimentation with Trichoderma against $H$. annosum spore infection using different strains, and also in combination with other stump-colonising fungi, including $P$. gigantea.

\section{ACKNOWLEDGEMENTS}

We would like to thank Jānis Donis for advice in mathematical calculations of data and Astra Zaluma and Natālija Arhipova for analysing the wood samples. This study was performed with financial support of European Regional Development Fund projects "Developing novel biological preparations to control the tree root rot caused by Heterobasidion spp." (2010/0277/2DP/2.1.1.1.0/10/APIA/VIAA/ 129) and "Methods and technologies for increasing forest capital value” (No. L-KC-11-0004).

\section{REFERENCES}

Arhipova, N., Gaitnieks, T., Donis, J., Stenlid, J., Vasaitis, R. (2011). Butt rot incidence, causal fungi and related yield loss in Picea abies stands of Latvia. Can. J. For. Res., 41 (12), 2337-2345.

Bendz-Hellgren, M., Stenlid, J. (1998). Effects of clear-cutting, thinning, and wood moisture content on the susceptibility of Norway spruce stumps to Heterobasidion annosum. Can. J. For. Res., 28 (5), 759-765.

Capretti, P., Mugnai, L. (1989). Saprophytic growth of Heterobasidion annosum on silver-fir logs interred in different types of forest soils. Eur. J. For. Path., 19 (5-6), 257-262.

Gaitnieks, T., Arhipova, N., Donis, J., Stenlid, J., Vasaitis, R. (2007). Butt rot incidence and related losses in Latvian Picea abies (L.) Karst. stands. In: Proceedings of the $12^{\text {th }}$ IUFRO International Conference on Root and Butt Rots. Garbelotto, M., Gonthier, M. (eds.). The University of California, Berkeley, pp. 177-179.

Gaitnieks, T., Arhipova, N., Nikolajeva, V., Vulfa, L., Balašova, I. (2009). Egḷu sakṇu rizosfēras mikrofloras antagonisms pret Heterobasidion annosum [Antagonism of microflora of spruce rhizosphere against Heterobasidion annosum]. Mežzinātne, 19 (52), 91-108 (in Latvian).

Gruduls, K., Gaitnieks, T., Donis, J., Liepa, I. (2012). Heterobasidion spp. in Picea abies understory: Incidence and impact on radial growth of trees. In: Proceedings of 18th Annual International Scientific Conference "Research for Rural Development”. Treija, S., Skuja, I. (eds.). Latvia University of Agriculture, Jelgava, pp. 21-24.

Hanso, M., Hanso, S. (1985). Search for antagonists to Heterobasidion annosum (Fr.) Bref. [Хансо, М., Хансо, С. Поиск антагонистов корневой губки. Лесоводственные исследования. Лесоводство]. Lesovodstennie issledovanija. Lesovodstvo, 20, pp. 122-152 (in Russian).

Holdenrieder, O., Greig, B. J. W. (1998). Biological methods of control. In: Heterobasidion annosum: Biology, Ecology, Impact and Control. Woodward, S., Stenlid, J., Karjalainen, R., Hüttermann, A. (eds.). CAB International, Wallingford, UK, pp. 235-258. 
Johansson, M., Marklund, E. (1980). Antagonists of Fomes annosus in the rhizosphere of grey alder (Alnus incana) and Norway spruce (Picea abies). Eur. J. For. Path., 10 (7), 385-395.

Kallio, T., Hallaksela, A.-M. (1979). Biological control of Heterobasidion annosum (Fr.). Bref. (Fomes annosus) in Finland. Eur. J. For. Path., 9 (5), 298-308.

Kenigsvalde, K., Donis, J., Korhonen, K.,Gaitnieks, T. (2011). Phlebiopsis gigantea skujkoku celmu bioloǵiskajā aizsardzībā pret Heterobasidion annosum s.l. izraisīto saknu trupi: literatūras apskats [Biological control of Heterobasidion root rot of coniferous stumps by Phlebiopsis gigantea: Literature review]. Mežzinātne, 23 (56), 25-40 (in Latvian).

Korhonen, K., Stenlid, J. (1998). Biology of Heterobasidion annosum. In: Heterobasidion annosum: Biology, Ecology, Impact and Control. Woodward, S., Stenlid, J., Karjalainen, R., Hüttermann, A. (eds.). CAB International, Wallingford, UK, pp. 43-70.

Kuhlman, E. G, Hendrix, F. F. (1964). Infection, growth rate, and competitive ability of Fomes annosus in inoculated Pinus echinata stumps. Phytopathology, 54 (5), 556-561.

La Porta, N., Ambrosi, P., Grillo, R., Korhonen, K. (2001). A study of the inoculum potential of Heterobasidion annosum in conifer stands of Alpine forests. Proceedings of the $5^{\text {th }}$ Congress of the European Foundation for Plant Pathology. Taormina - Giardini Naxos, pp. 289-294.

Lielpētere, A. (2009). Sakņu piepes mijiedarbība ar Trichoderma harzianum laboratorijas apstākḷos [Interaction between root and butt rot and Trichoderma harzianum in laboratory conditions]. Grām.: Biologiskie augu aizsardzības lìdzekḷi un mikrobioloǵiskie preparāti - cilvēku labklājībai. Bioefekts, Rīga, 26.-41. lpp. (in Latvian).

Lygis, V., Vasiliauskas, R., Stenlid, J. (2004). Planting Betula pendula on pine sites infested by Heterobasidion annosum: Disease transfer, silvicultural evaluation, and community of wood inhabiting fungi. Can. J. For. Res., 34 (1), 120-130.

Magnus, T. (2005). Heterobasidion root rot in Norway spruce. Modelling incidence, control efficacy and economic consequences in Swedish forestry. Swedish University of Agricultural Sciences, Department of Forest Mycology and Pathology. Doctoral thesis. 55 pp.

Meredith D. S. (1960). Further observations on fungi inhabiting pine stumps. Ann. Bot., 24 (1), 63-78.

Nicolotti, G., Gonthier, P., Varese, P. G. C. (1999). Effectiveness of some biocontrol and chemical treatments against Heterobasidion annosum on Norway spruce stumps. Eur. J. For. Path., 29 (5) 339-346.
Nicolotti, G., Gonthier, P. (2005). Stump treatment against Heterobasidion with Phlebiopsis gigantea and some chemicals in Picea abies stands in the western Alps. For. Path., 35 (5), 365-374.

Nikolajeva, V., Petrina, Z., Vulfa, L., Alksne, L., Eze, D., Grantina, L., Gaitnieks, T., Lielpetere, A. (2012). Growth and antagonism of Trichoderma spp. and conifer pathogen Heterobasidion annosum s.l. in vitro at different temperatures. Adv. Microbiol., 2 (3), 295-302.

Piri, T. (1996). The spreading of the $\mathrm{S}$ type of Heterobasidion annosum from Norway spruce stumps to the subsequent tree stand. Eur. J. For. Path., 26 (4), 193-204.

Pratt, J. E., Niemi, M., Sierota, Z. H. (2000). Comparison of three products based on Phlebiopsis gigantea for the control of Heterobasidion annosum in Europe. Biocontrol Sci. Techn., 10 (4), 467-477.

Rishbeth, J. (1951). Observations on the biology of Fomes annosus, with particular reference to East Anglian pine plantations. II. Spore production, stump infection, and saprophytic activity in stumps. Ann. Bot., 15 (1), $1-21$.

Scubert, M., Fink, S., Schwarze, F. W. M. R. (2008). In vitro screening of an antagonistic Trichoderma strain against wood decay fungi. Part I. Arboric. J., 31 (4), 227-248.

Sierota, Z., Kwaśna, H. (1998). Changes in fungal communities in abandoned farmland soil enriched with pine sawdust. Folia For. Pol./A-For., 40, 85-94.

Sun, H., Korhonen, K., Hantula, J., Kasanen, R. (2009). Variation in properties of Phlebiopsis gigantea related to biocontrol against infection by Heterobasidion spp. in Norway spruce stumps. For. Path., 39 (2), 133-144.

Vainio, E., Lipponen, K., Hantula, J. (2001). Persistence of a biocontrol strain of Phlebiopsis gigantea in conifer stumps and its effects on within-species genetic diversity. For. Path., 31 (5) 285-295.

Varese, G. C., Gonthier, P., Nicolotti, G. (2003). Impact of biological and chemical treatments against Heterobasidion annosum on non-target micro-organisms. In: Proceedings of $10^{\text {th }}$ IUFRO Conference on Root and Butt Rots. Laflamme, G., Bérubé, J. A., Bussières, G. (eds.). Canadian Forest Service, pp. 145-154.

Vasaitis, V., Stenlid, J., Thomsen, I., M., Barklund, P., Dahlberg A. (2008). Stump removal to control root rot in forest stands. A literature study. Silva Fenn., 42 (3), 457-483.

Vasiliauskas, R., Larsson, E., Larsson, K.-H., Stenlid, J. (2005). Persistence and long-term impact of Rotstop biological control agent on mycodiversity in Picea abies stumps. Biol. Control, 32 (2), 295-304.

Received 19 February 2014

Accepted in the final form 8 October 2016

\section{TRICHODERMA SP. IETEKME UZ HETEROBASIDION ANNOSUM ATTĪSTĪBU TRUPĒJUŠOS PAAUGAS EGL̨U CELMOS}

Heterobasidion annosum (Fr.) Bref. s.l izraisa ievērojamus ekonomiskos zaudējumus skujkoku mežos, tāpēc, lai samazinātu sakṇu piepes izplatību mežistrādes laikā, svaigi celmi tiek apstrādāti ar bioloǵiskajiem preparātiem. Laboratorijas apstākḷos ḷoti izteiktu antagonismu pret H. annosum uzrāda Trichoderma sp., tomēr ir samērā maz pētījumu lauka apstākḷos. Turklāt līdzšinējos pētījumos analizēta Trichoderma sp. ietekme uz $H$. annosum veselos skujkoku celmos. Mūsu pētījuma mērkis bija novērtēt Trichoderma sp. ietekmi uz $H$. annosum attīstību trupējušos paaugas eg̣̣u celmos. Pavisam tika analizēti 75 egḷu celmi. Daḷa celmu atstāti kontrolei, bet daḷa apstrādāti ar Trichoderma izolātiem. Darbā izmantoti T. viridescens un T. viride izolāti. H. annosum sastopamība analizēta 3 un 12 mēnešus pēc celmu apstrādes. Secināts, ka kontroles celmos $H$. annosum aizṇemtais veselās koksnes laukums ir lielāks, salīdzinot ar apstrādātajiem celmiem, tomēr atškirības nav būtiskas. 